\title{
Public-private cooperation and agricultural development in Sub-Saharan Africa: a review of Nigerian growth enhancement scheme and e-voucher program
}

\author{
Emmanuel Olatunbosun Benjamin ${ }^{1} \cdot$ Oreoluwa Ola $^{1} \cdot$ Hannes Lang $^{1} \cdot$ Gertrud Buchenrieder $^{2,3}$ (D)
}

Received: 19 August 2019 / Accepted: 7 December 2020 / Published online: 19 December 2020

(C) The Author(s) 2020

\begin{abstract}
The Growth Enhancement Scheme and e-voucher program, rolled out across Nigeria in 2011 by the federal government, provided the institutional basis for private agro-dealers to engage in the distribution of subsidized fertilizer, improved seeds and extension services to farmers. However, the impact of this policy on different modes of extension service delivery is still missing in literature. We apply an Ordinary Least Squared and Difference-in-Difference methodology on the (2010 and 2012) Living Standard Measurement Study of the World Bank. The results suggest that extension visitations as well as public extension services positively influence farm revenue. Furthermore, a substantial increase in fertilizer expenditure by farmers was observed, due to the e-voucher program, which could have contributed to the improved agricultural output witnessed in Nigeria postGrowth Enhancement Scheme era. Governments across Sub-Saharan Africa should implement policies that harness the economy of scale and scope of the private sector as well as information and communication technologies in delivering on time and adequate agricultural inputs to farmers.
\end{abstract}

Keywords Agricultural policy $\cdot$ Extension services $\cdot$ Fertilizer $\cdot$ Nigeria $\cdot$ Sub-Saharan Africa

\section{Introduction}

Policymakers consider access to agricultural extension services as pivotal to improved agricultural productivity and food security (Balgah et al. 2010; Davis 2008; Geppert et al. 2002; Krishnan and Patnam 2013). This is because access to extension services transmits valuable information that enhances the knowledge base of farmers as well as inputs such as fertilizer (Liverpool-Tasie et al. 2010). Several studies show significant returns as well as spillover benefits from agricultural extension services (Evenson 2001; Benjamin et al. 2018). These returns and spillover benefits manifest in the form of higher

Emmanuel Olatunbosun Benjamin emmanuel.benjamin@tum.de

1 Technical University of Munich (TUM), Alte Akademie 12 \& 14, 85354 Freising, Germany

2 Leibniz Institute of Agricultural Development in Transition Economies (IAMO), Theodor-Lieser-Straße 2, 06120 Halle (Saale), Germany

3 Universität der Bundeswehr München (UniBw M), Werner-Heisenberg-Weg 39, 85577 Neubiberg, Germany farm yields and revenues, improved efficiency, and access to credit among others (Davis 2008). Consequently, it is plausible to hypothesize that public investments in more effective agricultural extension services and technology can further improve farmer welfare (Anderson and Feder 2004).

Clearly, extension services influence the diffusion of information about and the adoption of agricultural technology (Aker 2011). The dissemination of information via extension services shows substantial variation, however. In sub-Saharan Africa, we can observe many types of measures, for instance print media, videos, folklore, group discussions, exhibitions, farm demonstrations as well as information and communication technology (Munyua 2000; Meinzen-Dick et al. 2011). The marginal effect of extension services is more pronounced in sub-Saharan Africa, where farming is an essential economic mainstay for large segments of the population, albeit with a decreasing share of the gross domestic product (GDP). A number of these extension service channels also distribute modern agricultural technology and inputs such as seeds.

In developing countries, Anderson and Feder (2004) and Davis (2008) analysed two channels of extension services: public extension services and private extension services. They argue that differences in their structure and 
agency influence outcomes at the farm level with regard to technology uptake and overall agricultural sector growth. Historically, the delivery of extension services has been under the purview of the public sector (Swanson 2008). However, governmental fiscal concerns, the presumably rather poor performance of public extension in fostering technology adoption in the past have raised interest in how public and/or private extension services can become more effective. Private sector extension agents in our case are private agro-dealers and/or for-profit non-governmental organizations (NGOs). Nigeria has the largest economy in Africa and aims for food security to sustain her growing population. A number of factors, among others, access to quality inputs, e.g. fertilizer, technology and information by farmers, are crucial for food security. Up until 2010 , public extension agents in Nigeria administered the extension services and the provision of inputs. A number of challenges ranging from rent-seeking, outdated information to lack of input delivery plagued the system. Major reforms under the Growth Enhancement Scheme (GES), implemented in the agricultural sector in 2010, have witnessed private agro-dealers entering the extension services and input distribution channels. This paper sets out to investigate how agricultural extension services (public versus private) enhanced the economic situation of farmers as well as the adoption of technology (inputs) in Nigeria.

Our investigation focuses specifically on fertilizer usage because between 1996 and 2002, average fertilizer usage per hectare in Nigeria was approximately $25 \mathrm{~kg}$ /ha and lower than the developing countries average of $102 \mathrm{~kg} / \mathrm{ha}$ in 2020 (Morris et al. 2007; Liverpool-Tasie and Takeshimab 2013. Prior to introducing the GES, fertilizers were primarily purchased and distributed to farmers via government extension agencies. Post GES, i.e. after 2011, private sector agro-agents - among other service delivery channels - now provide extension services and directly offer subsidized fertilizers to farmers (see Ayansina et al. 2015 and the next section for a literature review on the GES). Hence, we examine the role that private extension service agents play in the distribution of fertilizer under the GES in terms of their effectiveness and efficiency, and how it has affected fertilizer uptake.

Past studies found that the GES improved fertilizer adoption, farm revenues and raised general consumption expenditures among poor farmers (Liverpool-Tasie 2012, 2014; Wossen et al. 2017). However, these studies used crosssectional datasets which limits their ability to observe these improvements over time. Similarly, Nwalieji et al. (2015) found increased service delivery and a yearly increase in farmers' participation in the GES fertilizer e-voucher program in southeastern Nigeria. These studies argue that the use of panel data would draw firmer conclusions about the links between the GES and its impact on farm profit and fertilizer uptake.
Despite the positive outcomes realized from the GES, several old problems and new ones limit the Scheme's effectiveness. Liverpool-Tasie and Takeshimab (2013) expressed concerns regarding the quality and timely delivery of fertilizers. Others include low awareness of the GES among farmers, poor telephone network and little coverage in rural areas by private agro-dealers. Fadairo et al. (2015) highlight long distances to input redemption centres for the agro-dealers as the primary constraint restricting fertilizer uptake within the GES. Alabi and Adams (2017) find elite capture issues, namely that that the e-voucher program favours wealthier and more educated farmers. A 2017 report by the International Food Policy Research Institute (IFPRI) argues for a robust evidence-based analysis to support the policy efforts of the GES (IFPRI 2017). Likewise, Takeshima and Liverpool-Tasie (2015) suggest that a holistic evaluation of different aspects of agricultural production is needed to fully understand the impact of GES.

We contribute to the growing literature by ascertaining which types of extension services are most effective in improving farm revenue over time in Nigeria. We use farm revenue as a measure of performance of different types of extension services. Furthermore, we demonstrate to what extent input and extension services delivery by certified private agro-dealers under the GES increased fertilizer adoption over time in Nigeria. Our study analyses the linkage between farmers and private extension suppliers, and ascertains their effect on fertilizer uptake and the growth of farm revenues. We apply a panel ordinary least squared (OLS) regression and a Difference-in-Difference (DID) methodology to a panel dataset from Nigeria of the World Bank's Living Standards Measurement Study (LSMS) of 2010 and 2012. The OLS regression analysis measures and provides insights into the relationship between farm-level revenue and different types of extension services. The DID reveals the impact of the GES on fertilizer adoption after the introduction of the GES.

In Section 3, we provide a comprehensive literature review of the institutional extension service arrangements within which the Nigerian fertilizer sector is embedded. Section 4 outlines the theoretical analytical framework; it also provides a description of the data and the model estimation. Subsequently, the results of the empirical analysis as well as implications for national agriculture policy are discussed in Section 5. The paper then concludes in Section 6.

\section{The fertilizer sector in Nigeria}

Between 1976 and 1995, fertilizer was heavily subsidized, procured, and distributed to farmers by federal and state governments in Nigeria (Eboh et al. 2006). Nevertheless, public agencies encountered their own problems, implying government failure. They related among others to delayed delivery of fertilizers, taking advantage of price differential across states 
(arbitrage), fiscal issues due to the subsidization of fertilizers, rent seeking and corruption by public officials. These issues forced the federal government to embark on a series of reforms (Morris et al. 2007). These reforms started in 1995, when government transferred the responsibility of purchasing and distributing fertilizers to the private sector, followed by a complete phasing out of subsidies (Okoye 2003). These reforms were typical for structural adjustment programs recommended by the World Bank or the International Monetary Fund (IMF) to developing countries at the time (Riddell 1992). According to Nagy and Edun (2002), both reforms failed because proper institutional and infrastructural frameworks to facilitate private sector takeover of extension services and input distribution was missing. In combination with the subsidy removal, this drastically reduced fertilizer uptake among farmers and possibly farm yields and thus revenues, thus endangering Nigerian food security.

Subsequently, the federal and state governments reinstated fertilizer subsidies under in the Federal Market Stabilisation Program (FMSP) in 1999, albeit at lower rates (Nagy and Edun 2002; Banful and Olayide 2010). Under the FMSP, two market channels emerged (Takeshima and Nkonya 2014). In the first channel, government agencies procured fertilizers from private sector importers and marketers and distributed it to farmers at subsidized rates. In this channel (and before liberalization in 1995), Nigerian states typically distributed fertilizers via their agricultural ministries, Agricultural Development Programs (ADPs), or through state intermediaries. In the second channel, farmers purchased unsubsidized fertilizers in the commercial market. An empirical study by Takeshima and Nkonya (2014) revealed that farmers were more likely to purchase fertilizer in the first channel than the second channel. However, the first channel was rife with corruption, political manipulations, rent seeking, and lacked transparency (Takeshima and Nkonya 2014). Hence, farmers often complained about non-delivery, untimely delivery of fertilizers, and when delivered, poor quality of fertilizers, resulting in low fertilizer use (Banful and Olayide 2010). For instance, Druilhe and Barreiro-Hurlé (2012) observed that from 2002 to 2009 the average Nitrogen (N), Phosphates $\left(\mathrm{P}_{2} \mathrm{O}_{5}\right)$, Potash $\left(\mathrm{K}_{2} 0\right)$ fertilizer use in Nigeria was $5 \mathrm{~kg}(\mathrm{~kg})$ per hectare (ha), which was less than the sub-Saharan African average of $7.1 \mathrm{~kg}$ per ha and far below that of certain Eastern African countries of $30 \mathrm{~kg}$ per ha.

Correcting some of the challenges experienced before and after 1995 set the stage for the nationwide introduction of the voucher program (first paper vouchers, later evouchers) under the GES, which replaced the FMSP in 2010/11 (Nwajiuba 2012). According to the Nigerian Federal Ministry of Agriculture and Rural Development (FMARD 2016), the GES aimed to create self-sustaining farms and agribusinesses as well as to center private sector agents in the agricultural sector. One of its main policy moves was to reorganize the access to fertilizers by farmers and, in the same line, improve business opportunities for the private upstream market as regards the supply of fertilizers and other inputs. The GES enlists farmers in a national registry, connects them to certified private sector agro-dealers, and disseminates technical advice and extension services using Information Communications Technology such as mobile phones (FMARD 2016). The Scheme, initially piloted in four Nigerian states between 2004 and 2009, dispensed subsidized seeds and fertilizer paper vouchers (later e-vouchers) that farmers could redeem with certified private sector agro-dealers (Adebayo et al. 2016). The structure of GES bypassed state ministries and intermediaries as the mentioned agro-dealers now could sell inputs directly to farmers and provide extension services (FMARD 2016). Under the GES, farmers are entitled to $100 \mathrm{~kg}$ (two bags) of subsidized fertilizer per planting season, independent of farm size. The total subsidy then depends on the actual amount of fertilizer demanded and effectively supplied (Liverpool-Tasie and Takeshimab 2013). The cost of two $50 \mathrm{~kg}$ bags of unsubsidized fertilizer was -N-5000 (\$34) while a subsidy of $-\mathrm{N}-2000$ (\$13.6) was provided through the GES (Liverpool-Tasie and Takeshimab 2013).

While participation in the GES is voluntary and open to all farmers, Liverpool-Tasie (2014) argues that variables such as education, wealth, and social capital (e.g., social networks) may affect a farmer's ability to join the Scheme. This implies that participation in the GES is not random pointing to selection bias. However, our goal is to evaluate the impact of GES on fertilizer purchase among farmers participating in diverse models of extension services over time, selection bias, although important, is controlled in this study through the applied methodology.

Within the LSMS World Bank (2010 and 2012) data for Nigeria, 1327 farmers had received agricultural extension services by the public sector, but also increasingly from private agencies (see Table 1). This finding is in line with Munyua (2000). For simplicity, we classify all providers of extension services that are different from the governmental agricultural extension service as private. Table 1 demonstrates the diversity and complexity of agricultural extension service models in Nigeria. However, it is important to note that in reality the source of extension services and the tools are not mutually exclusive.

\section{Materials and methods}

In this section, we introduce the analytical framework, which is based on straightforward production theory, modelled using OLS regression and the DID regression. Furthermore, the data are described in detail. 
Table 1 Sources of extension services and extension tools in Nigeria

\begin{tabular}{lll}
\hline Sources of extension services $^{\mathrm{a}}$ & Frequency & Percent \\
\hline Public source & & \\
$\quad$ Governmental agricultural extension service & 172 & 12.96 \\
Private sources & & \\
Private agricultural extension service & 80 & 6.03 \\
Agricultural cooperative/farmer association & 25 & 1.88 \\
Non-governmental organization (NGO) & 5 & 0.38 \\
Extension measures (tools) & & \\
Peer farmer (neighbour/relative) & & 29.69 \\
Electronic media (TV, radio, etc.) & 394 & 32.25 \\
Village agricultural extension meeting & 428 & 6.48 \\
Lead farmers & 86 & 4.37 \\
Agricultural extension course & 58 & 0.30 \\
Others & 4 & 5.50 \\
Observations & 73 & 100.00 \\
\hline
\end{tabular}

Source: Adapted from World Bank LSMS (2010 and 2012)

$n=2$ observations missing. ${ }^{\text {a }}$ We dropped paper media (handouts/flyers) from our analysis due to its small representation in the sample. ${ }^{b}$ These extension measures could be used by both, the public or private extension service

\subsection{Analytical framework}

To analyse the relationship between farm revenue and the relevant independent variables such as inputs, i.e. fertilizer, public and private extension services, etc. over the two periods (2010 \& 2012) we apply a linear panel OLS regression. The (fixed-effect) equation is as follows:

$Y_{i t}=\alpha_{i}+\beta X_{i t}+u_{i t}(i=1,2, \ldots, n$ and $t=0,1)$

Where $Y_{i t}$ is the log total revenue generated from agricultural produce for an individual farmer. The subscript $i$ represents the total $n$ numbers of farmers at certain (two) points in time $t$. The explanatory variables of interest, $X$, comprise the number of extension service visitations as well as the different models of extension service provision, which could vary across farmers and time. Furthermore, individual farmers display certain observable and unobservable characteristics, which may influence their explanatory variables and which render farmers with similar predictors (within-cluster) substantially different. This means each intercept, $\alpha_{i}$, is unique (Wooldridge 2013). Thus, the intercept can be denoted as $\left.h\left(U_{i}\right)\right)$, where $U_{i}$ represents a vector of latent time-invariant confounders and $h(\cdot)$ is a random and unknown function (Imai and Kim 2016). The presence of these characteristics motivate several sources of bias notably, self-selection bias from farmers self-selecting into the treatment and omitted variables, which ensures that individual farmers' error terms and their predictor variables are correlated, thus producing biased coefficients. To obtain unbiased coefficients, we apply the fixed effects estimator. The fixed effects estimator assumes that individual characteristics might affect the dependent or independent variables and in estimating the relationship between the dependent and independent variable of interest, removes the effect of time-invariant characteristics. This provides a net coefficient estimate of the relationship between the dependent and independent variable. The application of the fixed effect methodology allows the unique intercept to vary for each individual to control for the effects of the (un)observable characteristics associated with each individual (Baltagi 2008; Wooldridge 2013). This approach gives an unbiased net effect of the independent variable on the dependent variable. Before opting for the fixed effect methodology, it is also important to ascertain that the unique time-invariant characteristics of individual farmers are uncorrelated with the unique characteristics of other farmers using the Hausman test.

The underlying assumption of the DID model adopted here is that if the GES (i.e., the active participation of the private extension service sector in input supply and information dissemination) had not been implemented after 2010, unobservable differences between farmers receiving public and other types of private extension services would remain the same over time. Thus, using cross-sectional data of post intervention alone might yield biased estimates as it neglects the "normal" difference between farmers that receive extension services including inputs from public (control group) and private (treatment group) extension sources. The DID therefore illustrates the change of fertilizer use over time due to the implementation of the GES. The mean of fertilizer purchased by farmers $i$ in the treatment group (1) and farmers in the control group ( 0$)$ at the pre-intervention period $(t=0)$ and post-intervention period $(t=1)$, is denoted as $\mu_{\mathrm{it}}$. The difference in mean between treatment and control group for preand post-intervention can be denoted as:

$\Delta F_{i}=\Delta F_{i 1}-\Delta F_{i 0}=\left(\mu_{11}-\mu_{10}\right)-\left(\mu_{01}-\mu_{00}\right)$

Where change in overall fertilizer purchase is denoted as $\Delta F$. The first term (that is $\Delta F_{i 1}$ ) on the right hand side in Eq. (3) is the change in fertilizer purchase for farmers engaging the services of private extension services and the second term (that is $\left.\Delta F_{i 0}\right)$ is the change in purchase by farmers using public extension services. We limit our sample to farm households for whom data is available for both, the period of pre-intervention fertilizer usage and the period for post-intervention fertilizer usage. We revert to available data on the total amount of fertilizer purchases in Nigeria currency naira (-N-) by farmers for the periods under consideration $2010(t=0)$ and $2012(t=$ 1). Following Wooldridge (2007), the model for this regression is therefore denoted as: 
$F_{i t}=\alpha_{0}+\beta_{1} X_{i t}+\beta_{2} Z_{i}+\beta_{3} T_{t}+\beta_{4} Z_{i} * T_{t}+u_{i t} \quad(i=0,1$ and $t=0,1)$

Where $F_{i t}$ denotes log form of overall fertilizer purchase over time in Naira. The amount of fertilizer purchased by each farmer at different intervention periods serves as measure of $F_{i t} . \alpha_{0}$ is the intercept. The term $X_{i t}$ represents key explanatory variables of individual farmers that are vital to fertilizer adoption namely education, farm size, age, distance to market, road, and urban area (Doss 2006). $Z_{i}$ is a dummy variable that indicates whether farmers are in the control (0) or treatment (1) group. Another dummy variable is the time variable, $T_{t}$, which take the value of zero $(t=0$; pre GES) and one $(t=1$; post GES). $\beta_{1}, \beta_{2}$ and $\beta_{3}$ are the coefficients of $X_{i t}, Z_{i}$ and $T_{t}$. $\beta_{4}$ is the coefficient of interaction term, $Z_{i} * T_{t}$ that is equivalent to the DID.

The use of a panel dataset and fixed effects estimator eliminates large variations in observable characteristics that are hypothesized to motivate selection bias while the DID estimator accounts for the differences between a treatment and control group due to the introduction of an intervention also eliminates selection bias.

\subsection{Data}

The World Bank administers the Living Standards Measurement Study (LSMS) in a number of developing countries, including Nigeria (World Bank 2017). In Nigeria, LSMS surveys were conducted in 2010, 2012 and 2015. While there are similarities between the questionnaires in both, the 2010 and 2012 survey, only certain questions in the 2015 survey retained the same format. Hence, we had to exclude the 2015 survey from our analysis, unfortunately.

The surveys encompassed household, agriculture, and community variables relating to post-planting and harvest parameters. For this study, the relevant data are found in the post-planting datasets. We merged household, agriculture, and community variables for 2010 and 2012 using household identification numbers for those involved in agricultural activities. The rationale behind this is that fertilizers and advisory services are typically demanded during and after planting seasons. Furthermore, we assume a time lag since the impact of the second phase (upscaling) of the GES would only be felt after 2010. We had an unbalanced panel dataset given that some farmers interviewed in 2010 were not captured in 2012 and vice versa.

The LSMS surveys cover all the six geo-political zones in Nigeria, see Table 2. Oseni and Winters (2009) argue that farm-related activities are concentrated in the northern zones, where more revenue is derived from agriculture as compared to the southern zones. In the southern zones, non-farm activities are more pronounced. Farms in the dataset are mostly
Table 2 Geo-political zones in Nigeria and farmer sub-samples

\begin{tabular}{lll}
\hline Zone & Frequency & Percentage \\
\hline North Central & 248 & 18.69 \\
North East & 105 & 7.91 \\
North West & 615 & 46.35 \\
South East & 261 & 19.67 \\
South South & 42 & 3.17 \\
South West & 56 & 4.22 \\
Total & 1327 & 100.00 \\
\hline
\end{tabular}

Source: Adapted from World Bank LSMS (2010 and 2012)

located (over 50\%) in the northern zones, which is implying a representative sample of the agricultural sector in Nigeria. For the purpose of this analysis, we only considered farmers older than 18 years ( $n=1327$ in total) who stated they had received either public or other types of extension services in all the six geo-political zones of Nigeria in 2010 and/or 2012.

Table 3 gives an overview of the summary statistics for all sampled farmers disaggregated by the type and measures of extension services i.e. treatment for private extension services and control for public extension services. Agricultural land in the sample was recorded in different units (heaps, ridges, stands, plots and acres). We used existing literature, e.g. Adebooye et al. (2006) in converting these units to hectares. The farm size in our sample, thus, ranges between 0 ha (lower bound) and 1761 ha (upper bound). The average farm size for the treatment group is estimated to be 7.57 ha (due to outliers), implying a substantial number of farms in Nigeria are rather medium-scale in terms of cultivated land. This somewhat aligns with Liverpool-Tasie (2012) findings that the average farm size cultivated by framers in Nigeria was between 3.5 and 4 ha. The control group are farmers with average farm size of 74 ha implying large-scale agricultural system. These control group farmers on average spend less on fertilizer and seed inputs compared to the treatment group. The control group farmers comprises more male farmers $(52 \%)$ while treatment group has more female farmers $(60 \%)$. Since more than half of the treatment group farmers in our sample were women, this may explain the zero farm size above as women respondents that use the land of their husbands or partners may not consider the land belonging to them but to their partners. The number of farmers in the treatment group that did not have formal education was higher $(62 \%)$ compared to those in the control group (36\%).

In terms of intake of food variety, which could be a proxy for food security, over $60 \%$ of the treatment group farmers indicated that they consumed different varieties of food every day - also see aggregated data in Table 4 . Only $0.59 \%$ of farmers in the control group reported that they were consuming the same type of food in the last 7 days. One percent of 
Table 3 Summary statistics of farmers

\begin{tabular}{|c|c|c|c|c|c|c|c|c|}
\hline \multicolumn{5}{|l|}{ Treatment } & \multicolumn{4}{|l|}{ Control } \\
\hline Variable & Mean & SD & Min & Max & Mean & SD & Min & Max \\
\hline Log farm revenue-crop sales $(-\mathrm{N}-)^{\mathrm{a}}$ & 9.58 & 1.66 & 5.70 & 16.58 & 10.19 & 2.20 & 5.19 & 12.42 \\
\hline Farm size (ha) & 7.57 & 34.18 & 0 & 400 & 74 & 348 & 0.01 & 1761 \\
\hline Fertilizer costs (-N-) & 7439 & 16,460 & 0 & 400,000 & 3102 & 8963 & 0 & 67,500 \\
\hline Seed costs (-N-) & 294.3 & 970.8 & 0 & 10,000 & 138.25 & 519 & 0 & 4000 \\
\hline Gender $(1=$ male, 2 = female $)$ & 1.60 & 0.48 & 1 & 2 & 1.48 & 0.5 & 1 & 2 \\
\hline Distance to urban center in km (pop. $>20,000$ ) & 25.4 & 19.3 & 0.2 & 98.8 & 23.75 & 23.7 & 0.6 & 98.9 \\
\hline Distance in $\mathrm{km}$ to tarred motor road & 14.4 & 19.8 & 0.1 & 100.2 & 18.6 & 24.3 & 0.2 & 102.1 \\
\hline Age (in years) & 41.5 & 17.3 & 19 & 100 & 45 & 16 & 19 & 98 \\
\hline Formal education $(1=$ yes, $2=$ no $)$ & 1.62 & 0.48 & 1 & 2 & 1.36 & 0.48 & 1 & 2 \\
\hline Days food variety was unavailable & 0.61 & 1.27 & 0 & 7 & 1.07 & 1.10 & 0 & 6 \\
\hline Savings with cooperatives etc. $(1=$ yes, $2=$ no $)$ & 1.99 & 0.09 & 1 & 2 & 1.95 & 0.19 & 1 & 2 \\
\hline Number of extension visitation per season & 1.29 & 2.15 & 0 & 15 & 1.81 & 1.23 & 0 & 5 \\
\hline Types and measure of extension services & 10 & 2.8 & 2 & 14 & 1 & 0 & 1 & 1 \\
\hline $\mathrm{N}$ & 1155 & & & & 172 & & & \\
\hline
\end{tabular}

Source: Adapted from World Bank LSMS (2010 and 2012)

${ }^{a}$ The exchange rate of US dollar (\$) to -N- from 2010 to 2012 was relatively stable at $\$ 1=-\mathrm{N}-153.5$ (CBN 2017)

treatment group farmers have used a saving facilities offered by a cooperative, saving association, or microfinance intermediary in the past compared to $5 \%$ among the control group farmers.

\section{Results}

For our OLS regression, we first ran a Hausmann test to determine whether to regress with fixed or random effect. The Hausman test result supports the use of a fixed effect regression model. As stated earlier, a fixed effect regression would

Table 4 Reduced variety of food consumption (insecurity) in the last 7 days

\begin{tabular}{lll}
\hline $\begin{array}{l}\text { Days food } \\
\text { variety was } \\
\text { unavailable }\end{array}$ & Frequency & Percentage \\
\hline 0 & 931 & 70.37 \\
1 & 125 & 9.45 \\
2 & 141 & 10.66 \\
3 & 74 & 5.59 \\
4 & 23 & 1.74 \\
5 & 17 & 1.28 \\
6 & 3 & 0.23 \\
7 & 9 & 0.68 \\
Total & 1323 & 100.00 \\
\hline
\end{tabular}

Source: adapted from World Bank LSMS (2010 and 2012) help control for the unique characteristics of each individual farmer. These unique characteristics give rise to a distinct constant and to error terms uncorrelated with that of other farmers. Table 5 depicts the OLS model results. Due to missing data for some of the control variables, we had a further reduction in the number of observations to 250 , depending on the regression model. We regress the log of farm revenues, i.e., sales revenues of crops on certain core variables in the first model. The results show that the conventional assumption is weakly satisfied as inputs, e.g. fertilizers, result in higher output (statistical insignificance). However, increasing the size of land would not necessarily lead to higher farm revenue or income. We also found a positive and statistically significant correlation between the number of extension service visitations and farm revenue. Given that we did not collect the data, it is impossible to attribute this visitation strictly to public extension services. On average, increasing the number of visitations from extension services results in a marginal increase in farm revenue. This result is consistent with the conventional wisdom on the relationship between farmers' welfare and their access to agricultural extension services (see Anderson and Feder 2004). The second model was estimated to establish the consistency of our basic model by controlling for the effect of education, gender, and proximity to urban centers on farm revenue. Greater distance to urban centers appears to have a negative impact on farm revenues as it is statistical significant and the results of the core model (1) remains unchanged. In model 3, the results also suggest that the further a farm is from an urban center with a population greater than 20,000 
Table 5 Effect of extension services on farm revenues from crop sales

\begin{tabular}{|c|c|c|c|}
\hline & $\begin{array}{l}(1) \\
\text { Model } 1\end{array}$ & $\begin{array}{l}\text { (2) } \\
\text { Model } 2\end{array}$ & $\begin{array}{l}\text { (3) } \\
\text { Model } 3\end{array}$ \\
\hline \multicolumn{4}{|l|}{ Farm \& socioeconomic control variables } \\
\hline Farm size (ha) & $\begin{array}{l}-0.00191 * * * \\
(1.54 \mathrm{e}-05)\end{array}$ & $\begin{array}{l}-0.00200 * * * \\
(2.25 \mathrm{e}-05)\end{array}$ & $\begin{array}{l}-0.00288^{*} \\
(0.000364)\end{array}$ \\
\hline Fertilizer cost (-N-) & $\begin{array}{l}7.14 \mathrm{e}-05 * * \\
(5.35 \mathrm{e}-06)\end{array}$ & $\begin{array}{l}4.21 \mathrm{e}-05 \\
(1.16 \mathrm{e}-05)\end{array}$ & $\begin{array}{l}2.61 \mathrm{e}-05 \\
(2.56 \mathrm{e}-05)\end{array}$ \\
\hline Seed costs (-N-) & $\begin{array}{l}4.56 \mathrm{e}-05 \\
(6.05 \mathrm{e}-05)\end{array}$ & $\begin{array}{l}0.000258 \\
(4.45 \mathrm{e}-05)\end{array}$ & $\begin{array}{l}0.000243 \\
(0.000145)\end{array}$ \\
\hline Gender $(1=$ male, $2=$ female $)$ & & $\begin{array}{l}-0.245 \\
(0.200)\end{array}$ & $\begin{array}{l}-0.406 \\
(0.112)\end{array}$ \\
\hline Distance to urban centre in km (population $>20,000$ ) & & $\begin{array}{l}-0.112 * * \\
(0.00680)\end{array}$ & $\begin{array}{l}-0.102 * \\
(0.0113)\end{array}$ \\
\hline Distance in $\mathrm{km}$ to tarred motor road & & & $\begin{array}{l}-0.289 * * \\
(0.0198)\end{array}$ \\
\hline Age (in years) & & & $\begin{array}{l}-0.0137 \\
(0.00424)\end{array}$ \\
\hline Formal education $(1=$ yes, $2=$ no $)$ & & $\begin{array}{l}-1.092 \\
(0.328)\end{array}$ & $\begin{array}{l}-1.029 * \\
(0.127)\end{array}$ \\
\hline Limitation of food variety consumption (days) & & & $\begin{array}{l}0.156 \\
(0.0949)\end{array}$ \\
\hline $\begin{array}{l}\text { Savings with microfinance banks and } \\
\text { cooperatives }(1=\text { yes, } 2=\text { no })\end{array}$ & & & $\begin{array}{l}0.222 \\
(0.0966)\end{array}$ \\
\hline Number of extension visitations & $\begin{array}{l}0.157 * * \\
(0.00433)\end{array}$ & $\begin{array}{l}0.187 * * \\
(0.00742)\end{array}$ & $\begin{array}{l}0.272 * * \\
(0.00500)\end{array}$ \\
\hline \multicolumn{4}{|l|}{ Private sources of extension services } \\
\hline Private agricultural extension service & & & $\begin{array}{l}-0.820 \\
(0.194)\end{array}$ \\
\hline Agricultural cooperative/farmer association & & & $\begin{array}{l}-4.191 * * * \\
(0.0615)\end{array}$ \\
\hline NGO & & & \\
\hline \multicolumn{4}{|l|}{ Extension measures $^{\mathrm{a}}$} \\
\hline Peer farmer (neighbor/relative) & & & $\begin{array}{l}-0.318^{*} \\
(0.0491)\end{array}$ \\
\hline Electronic media (TV, radio, etc.) & & & $\begin{array}{l}-0.543 * * \\
(0.0411)\end{array}$ \\
\hline Village agricultural extension meeting & & & $\begin{array}{l}-3.308^{* *} \\
(0.145)\end{array}$ \\
\hline Lead farmers & & & $\begin{array}{l}-1.269 \\
(0.265)\end{array}$ \\
\hline Agricultural extension course & & & $\begin{array}{l}-3.237 * * * \\
(0.00950)\end{array}$ \\
\hline Others & & & $\begin{array}{l}-0.820 \\
(0.166)\end{array}$ \\
\hline Constant & $\begin{array}{l}10.91 * * * \\
(0.126)\end{array}$ & $\begin{array}{l}16.75^{* *} \\
(0.272)\end{array}$ & $\begin{array}{l}28.65 * * * \\
(0.220)\end{array}$ \\
\hline Observations & 257 & 256 & 251 \\
\hline R-squared & 0.195 & 0.313 & 0.519 \\
\hline Number of ea & 55 & 55 & 51 \\
\hline
\end{tabular}

Merged World Bank LSMS (2010 \& 2012) based on household identification number

The dependent variable is farm revenue crops sales in -N-. Robust standard errors in parentheses. Significance levels are indicated as $* * * p<0.01, * *$ $p<0.05, * p<0.10$. ${ }^{\mathrm{a}}$ These extension measures could be used by both, the public and private extension service

inhabitants as well as a tarred road, the lower are the farm revenues generated. We also found that farmers who have some level of formal education tend to have lower farm revenues. Overall, the effect of the number of extension service visitations remains positive and statistically significant. The more pertinent question is, however, which source of extension service is more effective in increasing farmers' revenues. Thus, in model 3 we compare the effect of public extension services (baseline) to private extension services to identify their contribution to farm income.

\subsection{Effect of extension services on farm revenues}

From our results, we observed that private extension services, e.g. those offered by NGOs, may not be effective in increasing farm revenues as compared to public extension services. We 
however refrain from interpreting this result given the low number of farmers that had actually used extension services provided by NGOs and the possibility that only the poorest of the poor farmers participate in this type of extension services schemes (Benjamin and Blum 2015).

\subsection{Impact of the GES on fertilizer adoption}

In order to better understand the impact of the GES on farm productivity and revenue in Nigeria, we look at the distribution and purchase of fertilizer among farmers participating in private extension services after the introduction of the GES (see Table 6). We do this by estimating eq. [4]. However, we use the log of expenditures (in -N-) on fertilizer to normalize the dataset and allow for simple interpretation of the results.

Our results indicate that the formal education level does play a role in the purchase of fertilizer. However, we found that women farmers were more likely to acquire fertilizer compared to their male counterparts. Akramov (2009) and Chianu and Tsujii (2005) support these findings. According to our results, the likelihood of acquiring fertilizer is low for farmers located in more remote areas with poor infrastructure. This is in line with the study by Fadairo et al. (2015) who discovered long distance to input centers restricted fertilizer uptake under the GES.

From the DID regression, on the one hand, we find that there was an increase in the purchase of subsidized fertilizers among farmers. On the other hand, we also observed a reduction in the amount spent on fertilizer by all farmers after the introduction of the GES relative to the FMSP. This finding was statistically significant at the $1 \%$ level. We assume that streamlining and merging the distribution channels into one channel controlled by the private sector mitigated transaction costs for farmers associated with the old distribution system. The old distribution system was plagued with rent seeking, arbitrage and use of intermediaries making fertilizer unavailable and expensive (market rate). Another explanation could be that farmers participating in the e-voucher program are moving away from the old system, thereby reducing spending on this type of so-called "subsidized" fertilizer. The wider significance of this finding increases when we consider that the interaction (DID) shows that farmers receiving private agricultural extension services spent more on fertilizers after the introduction of the GES. This result seems to point at an increased participation of farmers in the GES. We tested different model specifications to ascertain the robustness of our coefficients. The coefficients were stable across three different model specifications (see Appendix in the supplementary file for more details).

\section{Discussion}

The results of our analysis show that as access to and number of visitations (contacts) from extension services increases, so does farm revenues in Nigeria. This implies that farmers having contact with extension services could improve overall farm revenue in Nigeria. Given the growing involvement and role of private sector esp. agro-dealers in extension services, aside the more established public extension services, in Nigeria it is important assess their impact on farm income. Our data analysis suggests that the farm revenues of farmer who have participated in private extension services may have decreased as compared to public extension services. Despite struggling with corruption, Omotayo et al. (2001) report that in the two decades between 1975 and 1995, public extension services in Nigeria performed relatively well due to the effect of the immense financial support from the World Bank while the potential of NGOs as one private player in the sector, was not fully harnessed. Akramov (2009) state that the public agricultural services have positively influenced the adoption of inputs among farmers in Nigeria, which in turn, would have a positive impact on revenue. Akramov (2009) and Omotesho et al. (2016) find that in parts of Nigeria, total annual income, farm size, access to credit, and training are factors that influenced farmer participation in public agricultural extension services. Farmers that do not participate in farmer-groups or in public agricultural extension arrangements often reverse to special agricultural development schemes or agricultural extension linked to NGOs (Omotesho et al. 2016). Our results not only suggest that the implementation of different types of private extension services in Nigeria may not contribute positively to farm revenue but the means of delivering these services need to be revisited. Akinnagbe and Ajayi (2010) state that the implementation of different types of extension services in Nigeria could lead to increased farm productivity among farmers, thus, higher revenue. Our results do not necessarily support this argument. Moreover, compared to public agricultural extension services, private agricultural extension services for the time of analysis (2010 \& 2012) were in the early development stage in Nigeria and their activities are sometimes constrained by scarce resources due to inconsistent donor funding and economic cycle (Adejo et al. 2012). Adejo et al. (2012) argue that the recent increase in the number of NGOs participating in extension services in Nigeria presents a challenge, as it could lead to the use of extension services as a competition mechanism for development aid rather than focusing on how to improve farmer's livelihood.

The effects of the post-intervention period of the GES (post2011) suggest there was an increase in spending on subsidized fertilizer by farmers, which may reflect the increase in enrolment in the e-voucher program by farmers and the rising number of certified private agro-dealers. Although availability of subsidized fertilizer did not increase, the probability that farmers will participate in the private agro-dealer market went up. Liverpool-Tasie (2012) found that farmers participating in the private agro-dealer market in Nigeria spent more on fertilizer. Akramov (2009) and IFDA (2017) also discover that the e-voucher program in parts of Nigeria resulted in a substantial number (above 30,000) of farmers who were registered just in 
Table 6 DID regression of sampled farmers using the LSMS for $2010 \& 2012$

\begin{tabular}{|c|c|c|c|c|}
\hline Log expenditure on fertilizer & $\begin{array}{l}(1) \\
\text { Model } 1\end{array}$ & $\begin{array}{l}(2) \\
\text { Model } 2\end{array}$ & $\begin{array}{l}\text { (3) } \\
\text { Model } 3\end{array}$ & $\begin{array}{l}(4) \\
\text { Model } 4\end{array}$ \\
\hline Formal education $(1=$ yes, $2=$ no $)$ & $\begin{array}{l}0.227 * \\
(0.122)\end{array}$ & $\begin{array}{l}0.227 * \\
(0.122)\end{array}$ & $\begin{array}{l}0.251 * * \\
(0.126)\end{array}$ & $\begin{array}{l}0.249 * * \\
(0.126)\end{array}$ \\
\hline Age (in years) & $\begin{array}{l}0.003 \\
(0.004)\end{array}$ & $\begin{array}{l}0.003 \\
(0.004)\end{array}$ & $\begin{array}{l}0.004 \\
(0.004)\end{array}$ & $\begin{array}{l}0.005 \\
(0.004)\end{array}$ \\
\hline Gender $(1=$ male, $2=$ female $)$ & $\begin{array}{l}0.268 * * \\
(0.107)\end{array}$ & $\begin{array}{l}0.273 * * \\
(0.107)\end{array}$ & $\begin{array}{l}0.266^{* *} \\
(0.111)\end{array}$ & $\begin{array}{l}0.255^{* *} \\
(0.111)\end{array}$ \\
\hline $\begin{array}{l}\text { Savings with microfinance } \\
\text { banks and cooperatives }\end{array}$ & & $\begin{array}{l}-0.342 \\
(0.544)\end{array}$ & $\begin{array}{l}-0.313 \\
(0.553)\end{array}$ & $\begin{array}{l}-0.301 \\
(0.563)\end{array}$ \\
\hline Farm size & & & $\begin{array}{l}-0.000^{* * *} \\
(0.000)\end{array}$ & $\begin{array}{l}-0.000 * * \\
(0.000)\end{array}$ \\
\hline Farm revenue & & & & $\begin{array}{l}0.000 * * * \\
(0.000)\end{array}$ \\
\hline $\begin{array}{l}\text { Distance to urban center in } \mathrm{km} \\
\quad \text { (population }>20,000)\end{array}$ & $\begin{array}{l}0.004 \\
(0.003)\end{array}$ & $\begin{array}{l}0.004 \\
(0.003)\end{array}$ & $\begin{array}{l}0.003 \\
(0.003)\end{array}$ & $\begin{array}{l}0.004 \\
(0.003)\end{array}$ \\
\hline Distance in $\mathrm{km}$ to tarred motor road & $\begin{array}{l}-0.005^{* *} \\
(0.002)\end{array}$ & $\begin{array}{l}-0.005^{* *} \\
(0.002)\end{array}$ & $\begin{array}{l}-0.005^{* *} \\
(0.002)\end{array}$ & $\begin{array}{l}-0.005^{* *} \\
(0.002)\end{array}$ \\
\hline $\begin{array}{l}\text { Treatment }(1=\text { farmers receiving } \\
\text { private extension, } \#=\text { else })\end{array}$ & $\begin{array}{l}-0.028 \\
(0.135)\end{array}$ & $\begin{array}{l}-0.018 \\
(0.134)\end{array}$ & $\begin{array}{l}-0.057 \\
(0.162)\end{array}$ & $\begin{array}{l}-0.077 \\
(0.160)\end{array}$ \\
\hline After reform (post GES) & $\begin{array}{l}-2.763 * * * \\
(0.125)\end{array}$ & $\begin{array}{l}-2.755^{* * * *} \\
(0.124)\end{array}$ & $\begin{array}{l}-2.793 * * * \\
(0.138)\end{array}$ & $\begin{array}{l}-2.782 * * * \\
(0.137)\end{array}$ \\
\hline Interaction (DiD) & $\begin{array}{l}3.302 * * * \\
(0.157)\end{array}$ & $\begin{array}{l}3.295 * * * \\
(0.157)\end{array}$ & $\begin{array}{l}3.331 * * * \\
(0.168)\end{array}$ & $\begin{array}{l}3.333 * * * \\
(0.168)\end{array}$ \\
\hline Constant & $\begin{array}{l}7.660 * * * \\
(0.312)\end{array}$ & $\begin{array}{l}8.327 * * * \\
(1.091)\end{array}$ & $\begin{array}{l}8.255^{* * *} \\
(1.111)\end{array}$ & $\begin{array}{l}8.233 * * * \\
(1.130)\end{array}$ \\
\hline Observations & 628 & 628 & 619 & 619 \\
\hline R-squared & 0.101 & 0.102 & 0.103 & 0.121 \\
\hline
\end{tabular}

Merged World Bank LSMS (2010 \& 2012) based on household identification number

Robust standard errors in parentheses. Significance levels are indicated as $* * * p<0.01, * * p<0.05, * p<0.1$ the second year of the program and who had access to seasonally maximum quantity of subsidized fertilizer (i.e., $100 \mathrm{~kg}$ ) and extension services from the private agro-dealers. Furthermore, IFDA (2017) observes that the use of mobile phones has made the e-voucher program accessible to over 30,000 farmers. Liverpool-Tasie and Takeshimab (2013) in their empirical analysis of the voucher program find that participants in the GES received more bags of subsidized fertilizer than non-participants. Our results suggest that farmers participating in the e-voucher program were able to access the maximum quantity of 3-4 bags of subsidized fertilizer à $50 \mathrm{~kg}$ over the two years (2010-2012) period confirming the findings of Liverpool-Tasie and Takeshimab (2013) and Wossen et al. (2017). As expected, participants of the e-voucher program pay a much lower price for the first two bags of fertilizer totaling $100 \mathrm{~kg}$ compared to those who purchased at market rates (Liverpool-Tasie and Takeshimab 2013). The decline in the amount spent by farmers on non-subsidized fertilizer (similar to the findings of Takeshima and Nkonya 2014) from private (certified as well as not certified) agro-dealers may signify a crowding out effect of the GES, especially if poor farmers are not targeted. This trend has been witnessed in government fertilizer subsidy programs across sub-Saharan Africa (see Takeshima et al. 2012; Jayne and Rashid 2013).

Based on the above discussion, there is a need to enact policies that target soft and hard infrastructure development. Soft infrastructure relates to smartphones and better access to the internet. This would reduce the transaction costs on the side of the government (e.g. for certification of private partners), the private extension service providers and agro-dealers (e.g. for registering and settling accounts with the government and farmers), and on the side of the farmers (e.g. for taking advantage of present and future e-programs of the government).

Obviously, hard infrastructure, such as road infrastructure is also important for economic development (IMF 2015), not the least for the effective supply of inputs such as fertilizer under the 
GES. It is worthwhile to mention that the road infrastructure must be all-weather and all-year but not necessarily tarmac roads (Heidhues and Schrieder 1993). The agricultural policy of the Nigerian Government should be designed to also deepen public and private sector partnership, not only for fertilizer distribution but also for local fertilizer production. A stronger partnership allows the private sector to leverage the structural and institutional infrastructure possessed by the public sector. Policies that would improve the business environment for private agrodealers should be encouraged. This could be in form of a tax break as well as the expansion of subsidies to other products (improved farm implements) and research and development (R\&D) offered by private extension services.

Given the finding that revenues among the farmers increase due to (effective) access to extension services, one could hypothesize that this will raise also tax revenues from the agricultural sector on the side of the Nigerian Government (in the medium and long run). Therefore, government spending on infrastructure and economic development go hand in hand.

This study is unique given that it uses a panel data to evaluate the GES and different models of extension services in Nigeria. Future research would benefit from utilizing a propensity score matching (PSM) technique to account for certain covariates, i.e. independent variables that predict farmers receiving certain types of extension services, alternatively, a randomized experiment. Both approaches would immensely reduce certain biases relating to confounding variables, which may also have been prevalent in our study.

\section{Conclusion}

The agricultural extension services in Nigeria have been undergoing substantial transformation since the introduction of the GES in 2011. The Scheme, piloted from the mid-2000s and scaled-up from 2011, uses an e-voucher program to provide subsidized fertilizer to farmers through private agro-dealers, up to a maximum of $100 \mathrm{~kg}$ per season. The GES was started to overcome irregularities within the public extension services and enhance agriculture development, i.e. improve farm revenue (productivity) and usage of inorganic fertilizer among farmers in Nigeria, because fertilizer use had been lagging behind the sub-Saharan African average. The questions that arise are: Which types of extension services are most effective in improving farmer revenue over time in Nigeria? Was the invitation of certified private agro-dealers in conjunction with extension services able to increase fertilizer adoption over time in Nigeria?

We used the World Bank LSMS dataset for the years 2010 and 2012 to answer these questions. Our results suggest that public (government) performed relatively well compared to private extension services in improving farm revenues among farmers in Nigeria. The former may be attributed to the immense structural advantages public extension services have over private extension services due to financial and technical support extended to the government extension services by the World Bank up to the 1990s. This could also be due to self-selection by elite farmers into public extension services. Our results do show that the involvement of the private sector in the GES, after the pilot phase, was able to increase fertilizer adoption (spending) among farmers in Nigeria. This implies that public-private programs and initiatives such as the GES may be an effective policy tool to attract private sector participation in the agricultural sector in Nigeria and the other sub-Saharan African countries.

Since the dataset was not specifically designed to address the research questions considered in this study, our analysis comes with a few limitations. For example, there was difficulty finding credible instrumental variables that would have allowed for more robust econometric analysis, conducting a more robust DiD parallel trends test or identifying variables that fully capture omitted variables or are suitable proxies for issues we wanted to measure.

Supplementary Information The online version contains supplementary material available at https://doi.org/10.1007/s12571-020-01130-y.

Acknowledgements We would like to thank AGLOBE DEVELOPMENT CENTER: https://aglobedc.org/ for their valuable intellectual feedback.

Funding Open Access funding enabled and organized by Projekt DEAL.

\section{Compliance with ethical standards}

Conflict of interest The authors declared that they have no conflict of interest.

Open Access This article is licensed under a Creative Commons Attribution 4.0 International License, which permits use, sharing, adaptation, distribution and reproduction in any medium or format, as long as you give appropriate credit to the original author(s) and the source, provide a link to the Creative Commons licence, and indicate if changes were made. The images or other third party material in this article are included in the article's Creative Commons licence, unless indicated otherwise in a credit line to the material. If material is not included in the article's Creative Commons licence and your intended use is not permitted by statutory regulation or exceeds the permitted use, you will need to obtain permission directly from the copyright holder. To view a copy of this licence, visit http://creativecommons.org/licenses/by/4.0/.

\section{References}

Adebayo, O., Olagunju, K.O., \& Ogundipe, A.A. (2016). Impact of agricultural innovation on improved livelihood and productivity outcomes among smallholder farmers in rural Nigeria.Working paper series 2015/07, Maastricht School of Management.

Adebooye, O. C., Ajadi, S. O., \& Fagbohun, A. B. (2006). An accurate mathematical formula for estimating plant population in a four dimensional field of sole crop. Journal of Agronomy, 5, 289-292.

Adejo, P. E., Okwu, O. J., \& Ibrahim, M. K. (2012). Challenges and prospects of privatization of agricultural extension service delivery in Nigeria. Journal of Agricultural Extension and Rural Development, 4(3), 63-68. 
Aker, J. C. (2011). Dial “A” for agriculture: a review of information and communication technologies for agricultural extension in developing countries. Agricultural Economics, 42(6), 631-647.

Akinnagbe, O. M., \& Ajayi, A. R. (2010). Challenges of farmer-led extension approaches in Nigeria. World Journal Agricultural Science, 6(4), 353-359.

Akramov, K.T. (2009). Decentralization, agricultural services and determinants of input use in Nigeria (Vol. 941). Washington, DC, USA: International Food Policy Research Institute (IFPRI).

Alabi, R.A., \& Adams, O.O. (2017). The pro-poorness of fertilizer subsidy and its implications on food security in Nigeria. Working paper series, African Economic Research Consortium (AERC). Nairobi, Kenya.

Anderson, J. R., \& Feder, G. (2004). Agricultural extension: good intentions and hard realities. The World Bank Research Observer, 19(1), 41-60.

Ayansina, S. O., Oyeyinka, R. A., \& Ayinde, A. F. O. (2015). Farmers' participation in the services of public and private extension organizations in southwestern Nigeria. British Journal of Applied Science \& Technology, 8(3), 238-245.

Balgah, A. R., Valentinov, V., \& Buchenrieder, G. (2010). Nonprofit extension in rural Cameroon: a study of demand and supply determinants. International Journal of Social Economics, 37(5), 391-399.

Baltagi, B. (2008). Econometric analysis of panel data. New York: John Wiley \& Sons.

Banful, A.B., \& Olayide, O. (2010). Perspectives of selected stakeholder groups in Nigeria on the federal and state fertilizer subsidy programs. IFPRI NSSP Report , 8 . Washington, DC, USA: International Food Policy Research Institute (IFPRI).

Benjamin, E. O., \& Blum, M. (2015). Participation of smallholders in agroforestry agri-environmental scheme: a lesson from the rural mount Kenyan region. The Journal of Developing Areas, 49(4), 127-143.

Benjamin, E. O., Ola, O., \& Buchenrieder, G. (2018). Does an agroforestry scheme with payment for ecosystem services (PES) economically empower women in sub-Saharan Africa? Ecosystem Services, 31, 1-11.

CBN - Central Bank of Nigeria. (2017). Monthly average exchange rates of the Naira (Naira Per Unit of Foreign Currency). Available online: https://www.cbn.gov.ng/rates/exrate.asp?year=2012 (Last visited: April 2015).

Chianu, J. N., \& Tsujii, H. (2005). Determinants of farmers' decision to adopt or not adopt inorganic fertilizer in the savannas of northern Nigeria. Nutrient Cycling in Agroecosystems, 70(3), 293-301.

Davis, K. E. (2008). Extension in sub-Saharan Africa: overview and assessment of past and current models, and future prospects. Journal of International Agricultural Extension Education, 15, 15-28.

Doss, C.R. (2006). Analysing Technology Adoption Using Microstudies: Limitations, Challenges and Opportunities for Improvement. Agricultural Economics, 35, 207-219

Druilhe, Z., \& Barreiro-Hurlé, J. (2012). Fertilizer subsidies in subSaharan Africa. No. 12-04 ESA Working Paper.

Eboh, E.C., Ujah, O.C., \& Amaechina, E.C. (2006). Do government fertiliser subsidies benefit rural poor farmers in Nigeria? Making sense out of existing data. PMMA Network Session Paper. Available online at: http://anciensite.pep-net.org/fileadmin/medias/pdf/files_events/5th ethiopia/Oliver_Ujah.pdf (Last visited: June 2018).

Evenson, R. E. (2001). Economic impacts of agricultural research and extension. Handbook of Agricultural Economics, 1, 573-628.

Fadairo, O. S., Olutegbe, N. S., \& Tijani, A. M. (2015). Attitude of crops ewallet platform of the growth enhancement support scheme in OkeOgun area of Oyo state. Journal of Agricultural Informatics, 6(2), 62-71.

FMARD - Federal Ministry of Agriculture and Rural Development. (2016). The Agriculture Promotion Policy (2016-2020) Building on the Successes of the ATA, Closing Key Gaps Policy and Strategy Document. Federal Ministry of Agriculture and Rural Development Report. Available at: http://fscluster.org/sites/default/ files/documents/2016-nigeria-agric-sector-policy-roadmap june15-2016_finall.pdf (Last visited: June 2018).
Geppert, M., Dang, T. N., \& Buchenrieder, G. (2002). Participatory agricultural research and decentralization in Vietnam. Journal of Agricultural Education and Extension, 8(4), 171-180.

Heidhues, F., \& Schrieder, G. (1993). The role of infrastructure components for rural households' access to financial markets: A case study of Cameroon. In Regional food security and rural infrastructure. Vol. II, H.-U. Thimm and H. Hahn (Eds.). Berlin, D: LIT Publisher.

IFDA - International Fertilizer Development Center. (2017). National Fertilizer Policy for Nigeria. Available at: https://ifdc.org/nigeriafertilizer-voucher-program/ (Last visited: June 2018).

IFPRI - International Food Policy Research Institute. (2017). Nigeria strategy support program (NSSP). Washington DC, USA: International Food Policy Research Institute, available online: https://www.ifpri.org/program/nigeria-strategy-support-program (Last visited: May 2015)

Imai K., \& Kim, I.S. (2016). When should we use linear fixed effects regression models for causal inference with longitudinal data? Working paper, Princeton University, Princeton, NJ.

IMF - International Monetary Fund. (2015). Making public investment more efficient. Washington, DC, USA: International Monetary Fund (IMF), available at: www.imf.org/external/np/pp/eng/2015/ 061115.pdf (Last visited: July 2017).

Jayne, T. S., \& Rashid, S. (2013). Input subsidy programs in sub-Saharan Africa: a synthesis of recent evidence. Agricultural Economics, 44(6), 547-562.

Krishnan, P., \& Patnam, M. (2013). Neighbors and extension agents in Ethiopia: who matters more for technology adoption? American Journal of Agricultural Economics, 96(1), 308-327.

Liverpool-Tasie, L.S. (2012). Targeted subsidies and private market participation: An assessment of fertilizer demand in Nigeria. IFPRI discussion paper 1194. Washington, D.C., USA: International Food Policy Research Institute (IFPRI).

Liverpool-Tasie, L. S. O. (2014). Do vouchers improve government fertilizer distribution? Evidence from Nigeria. Agricultural Economics, 45(4), 393-407.

Liverpool-Tasie, S. O., \& Takeshimab, H. (2013). Input promotion within a complex subsector: fertilizer in Nigeria. Agricultural Economics, 44, 581-594.

Liverpool-Tasie, S., Olaniyan, B., Salau, S., \& Sackey, J. (2010). A review of fertilizer policy issues in Nigeria. Washington, DC: International Food Policy Research Institute (IFPRI).

Meinzen-Dick, R., Quisumbing, A., Behrman, J., Biermayr-Jenzano, P., Wilde, V., Noordeloos, M., \& Beintema, N. (2011). Engendering agricultural research, development and extension. Washington, D.C: International Food Policy Research Institute (IFPRI).

Morris, M., Kelly, V. A., Kopicki, R. J., \& Byerlee, D. (2007). Fertilizer use in African agriculture: Lessons learned and good practice guidelines. Washington, D.C.: World Bank.

Munyua, H. (2000). Application of information communication technologies in the agricultural sector in Africa: A gender perspective. In E. Rathgeber \& E. O. Adera (Eds.), Gender and information revolution in Africa (pp. 85-123). Ottawa: International Development Research Center-IDRC.

Nagy J.G., \& Edun, O. (2002). Assessment of Nigerian government fertilizer policy and suggested alternative market-friendly policies. State College, Pennsylvania, USA: Penn State University, available at: http://citeseerx.ist.psu.edu/viewdoc/download?doi=10.1.1.594. 2361\&rep=rep 1\&type=pdf (Last visited June 2015).

Nwajiuba, C. (2012). Nigeria's agriculture and food security challenges. Berlin, D: HeinrichBöll Foundation, available online: www.boell. org/downloads/4_Green_Deal_Nigeria_AGRICULTURE.Pdf (Last visited April 2015).

Nwalieji, H. U., Uzuegbunam, C. O., \& Okeke, M. N. (2015). Assessment of growth enhancement support scheme among rice farmers in Anambra state, Nigeria. Journal of Agricultural Extension, 19(2), 71-81. 
Okoye, C. U. (2003). Analysis of agricultural input subsidy policies in Nigeria. Study Report Submitted to the World Bank Country Office.

Omotayo, A., Chikwendu, K. D., \& Kola Adebayo, K. (2001). Two decades of World Bank assisted extension services in Nigeria: lessons and challenges for the future. The Journal of Agricultural Education and Extension, 7(3), 143-152.

Omotesho, K. F., Ogunlade, I., Lawal, M. A., \& Kehinde, F. B. (2016). Determinants of level of participation of farmers in group activities in Kwara state, Nigeria. Gaziosmanpaşa Üniversitesi Ziraat Fakültesi Dergisi, 33(3), 21-27.

Oseni, G., \& Winters, P. (2009). Rural nonfarm activities and agricultural crop production in Nigeria. Agricultural Economics, 40(2), 189-201.

Riddell, J. B. (1992). Things fall apart again: structural adjustment programmes in sub-Saharan Africa. The Journal of Modern African Studies, 30(1), 53-68.

Swanson, B. E. (2008). Global review of good agricultural extension and advisory service practices. Rome: Food and Agriculture Organization of the United Nations.

Takeshima, H., \& Liverpool-Tasie, L. S. O. (2015). Fertilizer subsidies, sub-Saharan Africa: evidence from Nigeria. Food Policy, 54, 11-24.

Takeshima, H., \& Nkonya, E. (2014). Government fertilizer subsidy and commercial sector fertilizer demand: evidence from the Federal Market Stabilization Program (FMSP) in Nigeria. Food Policy, 47, 1-12.

Takeshima, H., Nkonya, E., \& Deb, S. 2012. Impact of fertilizer subsidies on the commercial fertilizer sector in Nigeria: Evidence from previous fertilizer subsidy schemes. NSSP policy note 34 . Washington, D.C.: International Food Policy Research Institute (IFPRI).

Wooldridge, J. (2007). What's new in econometrics? Lecture 10 difference-in-differences estimation. NBER Summer Institute, available online: www.nber.org/WNE/Slides7-31-07/slides_10_ diffindiffs.pdf (Last visited: April 2016).

Wooldridge, J. M. (2013). Introductory econometrics: A modern approach (Fifth ed.). Nelson Education.

World Bank (2017). Living Standard Measurement Study (LSMS) LSMS Dataset Finder. Available at: http://iresearch.worldbank.org/ lsms/lsmssurveyFinder.htm (Last visited: June 2018).

Wossen, T., Abdoulaye, T., Alene, A., Feleke, S., Ricker-Gilbert, J., Manyong, V., \& Awotide, B. A. (2017). Productivity and welfare effects of Nigeria's e-voucher-based input subsidy program. World Development, 97, 251-265.

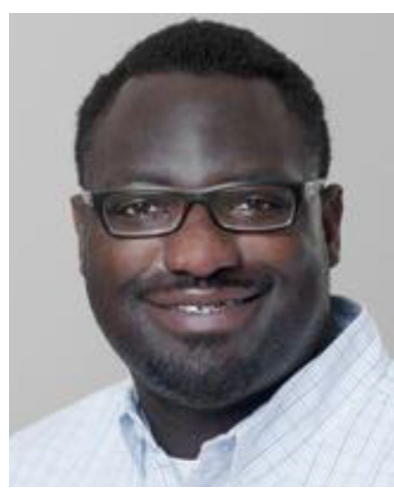

Dr. Emmanuel Olatunbosun Benjamin is currently a senior researcher with the Department of Agricultural Production and Resource Economics at the Technical University of Munich (TUM) Germany and affiliated to AGLOBE DEVELOMENT CENTER in Nigeria. He has led work-package of European Union (EU) project as well as collaborative research in the field of agricultural and resource economics with a number of European and African Institutes. He has published widely in a number of international journals and served on the advisory board of projects.

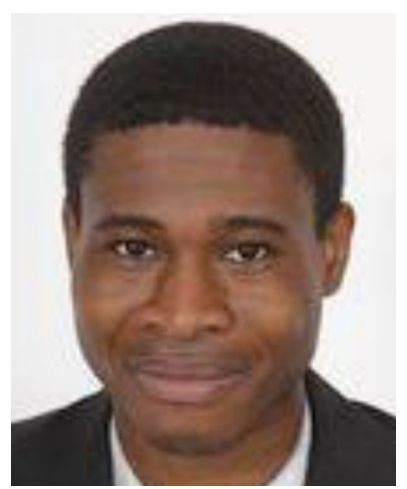

Mr. Oreoluwa Ola is currently a $\mathrm{PhD}$ student with the Department of Governance in International Agribusiness at the Technical University of Munich (TUM), Germany. Mr. Ola's areas of interest lie in agricultural and development economics; focusing specifically on various agricultural value-chain related issues, including the welfare and relationships among value chain actors, food quality and sustainability.

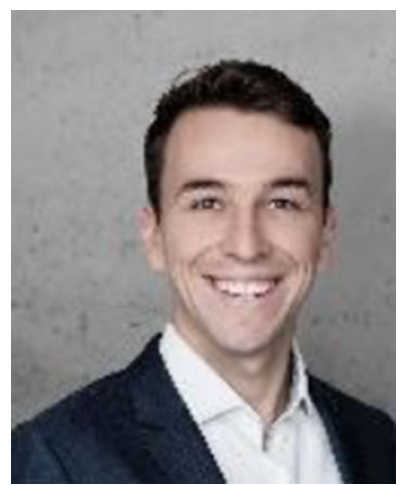

Dr. Hannes Lang received his Ph.D. in Ecological Economics at Rensselaer Polytechnic Institute under the guidance of Professor John Gowdy. After he finished his Ph.D. he worked as a consultant for a project in South Sudan funded by UNEP and as a Postdoc at the Technical University of Munich. Dr. Lang is now a consultant at TWS Partners in Munich, specializing in the application of game theory in procurement and negotiations.

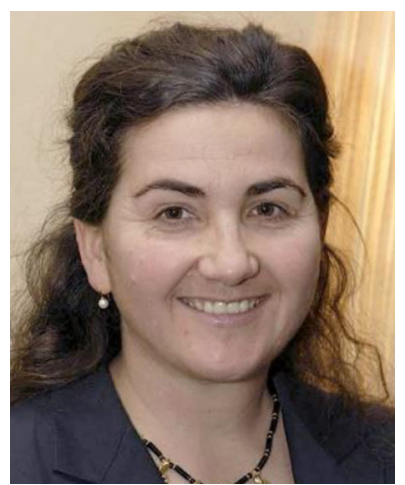

Prof. Dr. Gertrud Buchenrieder received her doctoral degree (1994) at the University of Hohenheim, Germany, researching the interrelationship of food security and rural finance in Cameroon. In her post-doctoral, she did a cross-country comparison of financial market transition in Central and Eastern Europe. Since then she has held several university positions as professor in the field of development economics with a focus on rural areas. Broadly speaking, she is interested in the inclusive sustainable socio-economic development of developing and transition countries 